\title{
Pasture persistence: how much is it worth?
}

\author{
R. BRAZENDALE ${ }^{1,}$ J.R. BRYANT ${ }^{2}$, M.G. LAMBERT ${ }^{3}$, C.W. HOLMES ${ }^{4}$, T.J.FRASER ${ }^{5}$ \\ ${ }^{1}$ DairyNZ, Massey University, Private Bag 11-222, Palmerston North \\ ${ }^{2}$ AgResearch, C/- Farmax Limited, P O Box 1036, Hamilton 3240 \\ ${ }^{3}$ AgResearch, Grasslands, Private Bag 11-008, Palmerston North, 4442
}

${ }^{4}$ Turitea, Palmerston North

${ }^{5}$ AgResearch, Lincoln

Corresponding author: Rob Brazendale, DairyNZ, Massey University, Private Bag 11222, Palmerston North 4442 rob.brazendale@dairynz.co.nz

\begin{abstract}
The farm system model, Farmax Dairy Pro, was used to evaluate the impact of new pastures on dairy farm profitability, assuming a range of pasture yields and qualities, and different levels of persistence in the new pastures, which were established on $10 \%$ of the farm annually. Scenarios were tested for Waikato, Taranaki, Canterbury and Southland dairy farm systems.
\end{abstract}

Assuming a \$6.50/kg MS milk payment and a response to pasture renewal of $10 \%$ in dry matter yield and a $0.6 \mathrm{MJ} \mathrm{ME} / \mathrm{kg} \mathrm{DM}$ increase in quality, increasing persistence from 4 years up to 8 years was modelled to increase dairy farm profitability by $\$ 271 /$ ha to $\$ 478 / \mathrm{ha}$.

Management practices, including selections of cultivars and endophytes, that improve pasture persistence are likely to increase dairy farm profitability. Keywords: dairy farms, modelling, pasture renewal, persistence

\section{Introduction}

The rate of pasture renewal amongst New Zealand dairy farmers has been estimated at $6 \%$ (Sanderson et al. 2009). If this rate was to be increased to $12 \%$ p.a. the increase in dairy industry output was calculated to be $\$ 800 \mathrm{~m}$ p.a. (Sanderson et al. 2009). This represents an apparent and significant opportunity for the industry however, for dairy farmers to increase their investment in pasture renewal, the benefits must translate into extra profit at the individual dairy farm business level.

A DairyNZ-commissioned survey carried out by AgResearch (Kelly et al. 2010) of 800 Waikato and Bay of Plenty farmers found that the most frequently cited factor limiting improvement in pasture performance on-farm was the persistence of the new pastures. The results showed a diminishing level of satisfaction as the age of the pasture increased from establishment to 3 years. Clearly, this perception is likely to be a barrier to further investment in pasture renewal by farmers.

The return on investment from pasture renewal is largely dependent on two variables: The amount of extra energy eaten and converted to product as a result of renewing the pasture (relative yield advantage) and the duration of this relative yield advantage, when compared with a non-renewed pasture (persistence).

Evaluations of pasture cultivars are normally reported in terms of increased yield ( $\mathrm{kg} \mathrm{DM})$ and improved quality (MJ ME/kg DM). Few studies have evaluated the impact of new cultivars or pasture mixes within a whole farm context, but Glassey et al. (2010) and McLean et al. (2010) are two notable exceptions. In these studies the impact of more persistent pastures on whole farm profitability has been not reported.

An earlier study, also using the farm system model Farmax Dairy Pro, evaluated the impact on farm profitability of a range of pasture yields and quality, and two levels of persistence in new pastures (Bryant et al. 2010b). Scenarios were tested for Waikato, Taranaki, Canterbury and Southland dairy farm systems. However, the main focus of this earlier study was the impact on profitability of integrating crops into the pasture renewal process and this was fully reported. Furthermore, Bluett et al. (2004) and Gerrard et al. (2009) have shown cropping to be beneficial to the establishment of new pastures.

The purpose of this study was to simulate the effects of persistence of new pastures on whole-farm profitability, following old pasture to new pasture (i.e., without cropping). Those simulations by Bryant et al. (2010b) which did not include the integration of crops will be reported here. The inclusion of cropping sequences would confound the economic analysis of persistence which is the focus of this paper.

\section{Material and Methods}

A simulation approach was adopted using Farmax Dairy Pro (Bryant et al. 2010a). Farmax Dairy Pro is a decision support model that uses monthly estimates of pasture growth, farm and herd information to determine production and economic outcomes of managerial decisions. The model has been validated against a several data sets, and has been shown to predict with an acceptable level of accuracy (within $6 \mathrm{~kg} \mathrm{MS} / \mathrm{cow}$, and $20 \mathrm{~kg} \mathrm{MS} / \mathrm{ha}$ ) (Bryant et al. 2010a). In the present study, representative farms in Waikato, Taranaki, 
Canterbury (irrigated) and Southland were simulated. The base farms were developed based on consultations with industry experts, and assuming average genetic merit herds. The base farms did not include a renewal or cropping component. A summary of the physical performance of these farms is provided in Table 1. DairyNZ 2009/2010 forecast expenses were used for each region. A milk price of $\$ 6.50 / \mathrm{kg}$ MS was assumed.

\section{Old pasture-new pasture scenarios}

Old pasture into new pasture scenarios were simulated on $10 \%$ of the farm's area per year, and it was assumed that new pastures would be excluded from the grazing rotation for a period of 40 days after sowing. Pasture renewal commenced on the $20^{\text {th }}$ of March for Waikato and Taranaki, and the $1^{\text {st }}$ of December for Canterbury and Southland. Pasture renewal was assumed to cost $\$ 600 /$ ha.

In the first scenario, no benefits in pasture production or quality due to renewal were assumed. Simulations were subsequently repeated assuming all combinations of the benefits outlined below for renewed paddocks:

- Pasture production boost on renewed blocks in the first year following renewal of; $+10,20$ or $30 \%$

- Pasture quality boost: +0.3 or $0.6 \mathrm{MJ} \mathrm{ME} / \mathrm{kg} \mathrm{DM}$

- Persistence: 4 or 8 years

Persistence was represented by simulating approximately linear reductions in pasture production and quality over time. For instance, for $+10 \%$ pasture production and $+0.3 \mathrm{MJ} \mathrm{ME} / \mathrm{kg}$ DM increase in quality combination with a 4-year persistence, the area of the farm subject to renewal was represented as four blocks, each constituting $10 \%$ of the farm's area. Production and quality increases ranged from $10 \%$ and $+0.3 \mathrm{MJ}$ $\mathrm{ME} / \mathrm{kg} \mathrm{DM}$ (in the first year after renewal) to $2.5 \%$ and $0.075 \mathrm{MJ} \mathrm{ME} / \mathrm{kg} \mathrm{DM}$ (in the fourth year after renewal) to represent a linear decline over time.

\section{Decision rules}

In scenarios where pasture production was increased, the following rules were applied to ensure pasture covers at start and end were within $+/-20 \mathrm{~kg}$ DM of the base simulations:

1. Higher pasture intakes per cow and higher milk yields per cow, with no increase in cows per ha

2. Delayed dry off date, with longer lactations (days in milk)

No additional supplements were bought in, and nitrogen application rates and dates stayed the same.

\section{Results and discussion}

The old pasture-new pasture renewal regime increased profit when the new pastures persisted for at least 4 years, and there was either a $10 \%$ increase in pasture production or a $0.6 \mathrm{MJ} \mathrm{ME} / \mathrm{kg} \mathrm{DM}$ increase in energy content. If pasture yield did not increase after renewal, profitability was found not to increase unless there was an increase of 0.4 to $0.5 \mathrm{MJ} \mathrm{ME} / \mathrm{kg} \mathrm{DM}$ in energy content after renewal. Increased pasture quality in the $10 \%$ of farm renewed each year is worth about $\$ 43$ or $\$ 78 /$ ha for every additional $0.1 \mathrm{MJ} \mathrm{ME} / \mathrm{kg} \mathrm{DM}$, assuming 4- or 8-year persistence of new pasture respectively. Similarly, with 4- or 8-year persistence, every $10 \%$ increase in yield production on renewed paddocks is worth $\$ 305$ or $\$ 449 /$ ha respectively.

The impact of pasture persisting for 4 or 8 years is highly dependent on the magnitude of the increase in

Table 1: Summary of performance of the regional base farms with no pasture renewal or cropping.

\begin{tabular}{lcccc}
\hline & Waikato & Taranaki & Canterbury & Southland \\
\hline Effective area (ha) & 119 & 91 & 200 & 171 \\
Peak cows milked & 378 & 278 & 788 & 361 \\
Stocking rate (cows/ha) & 3.2 & 3.1 & 3.9 & 1237 \\
Milksolids (kg/ha) & 1106 & 1033 & 3.3 \\
Milksolids (kg/cow) & 348 & 338 & 379 & 377 \\
Lactation length (days) & 271 & 261 & 269 & 254 \\
Condition score at calving & 4.8 & 4.7 & 4.8 & 149 \\
Pasture eaten (t DM/ha) & 13.1 & 12.7 & 15.9 & 13.2 \\
Average pasture metabolisable energy (MJ/kg DM) & 11.1 & 11.1 & 11.6 & 11.2 \\
Forage crops (t DM/ha) & 0.0 & 0.0 & 0.0 & 0.0 \\
Bought-in feeds (t DM/ha) & 1.2 & 0.8 & 1.1 \\
Total feed eaten (t DM/ha) & 14.5 & 14.1 & 18.7 & 14.6 \\
Total supplements / feed eaten (\%) & 10.1 & 9.4 & 15.2 & 9.5 \\
\hline
\end{tabular}


Figure 1 Change in profitability for the farms with renewed pastures (10\% of their area renewed/year), when compared to the base farms. The following ranges of performance were assumed for the new pastures; increases in pasture yield $(=$ $0 \%,=10 \%$, = $=20 \%, \boldsymbol{m}=30 \%)$, increases in pasture quality $(0,0.3$ or $0.6 \mathrm{ME} \mathrm{ME} / \mathrm{kg} \mathrm{DM})$ and persistence of either $4(4 \mathrm{yr})$ or 8 years $(8 \mathrm{yr})$.

Waikato

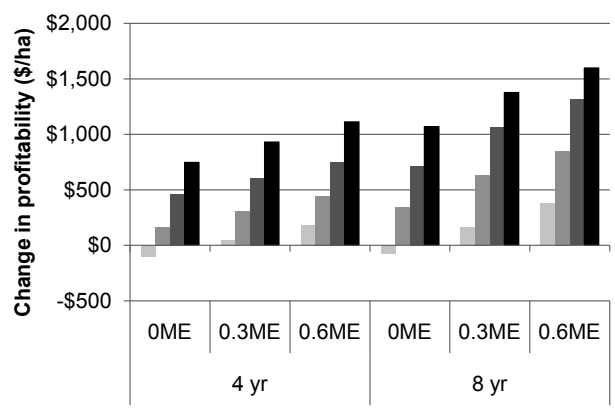

Canterbury

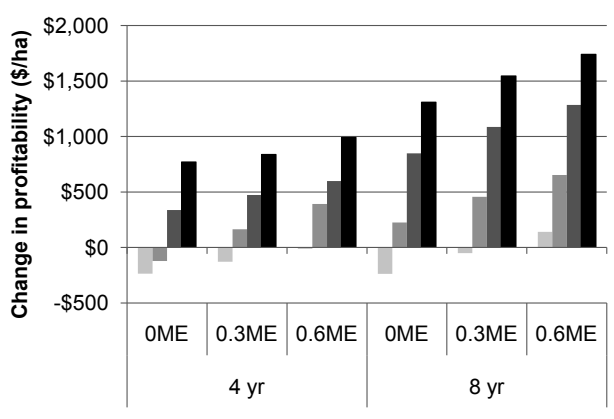

Southland

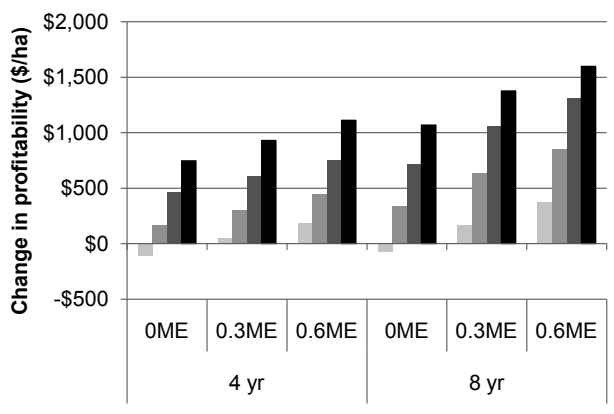

Taranaki

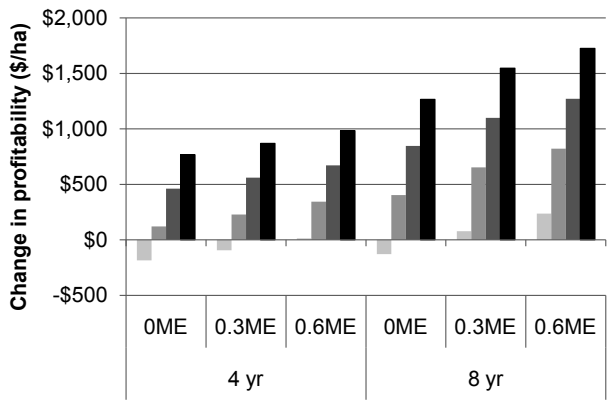

yield (t DM/ha) and in energy (ME MJ/kg DM (Fig. 1)). Glassey et al. (2010) reported increases in dry matter yield of 5-11\% and 0.5-0.9 MJ ME/kg DM when renewed pasture was compared with old pasture. Hainsworth et al. (1991) reported a $12 \%$ increase in pasture yield, while Dalley (2010) found an increase in energy content of $0.6 \mathrm{MJ} \mathrm{ME} / \mathrm{kg} \mathrm{DM}$ in new pastures compared to old.

These findings indicate that increases of $10 \%$ in yield and $0.6 \mathrm{MJ} \mathrm{ME} / \mathrm{kg} \mathrm{DM}$ can reasonably be expected. If these benefits persist for 8 years rather than only 4 years, farm profitability would be expected to increase by $\$ 425 /$ ha for the Waikato model, by $\$ 478 /$ ha for Taranaki, by $\$ 261 /$ ha for Canterbury, and by $\$ 408 /$ ha for Southland. The higher values for Waikato and Taranaki could be attributable to these regions performing to a lower level of base milk solids production per cow and with lower ME concentration of pasture. Additional DM or energy in these regions is more valuable as it helps to achieve a greater dilution of maintenance and higher proportion of total extra energy partitioned towards milk production than for Canterbury and Southland.

\section{Conclusions}

This modelling exercise showed that increasing the persistence of new pastures, from 4 years up to 8 years, has a significant impact on whole farm profitability. Management practices, including selection of cultivars and endophytes, that contribute to increases in pasture persistence have the potential to increase whole-farm profitability. This information may assist farmers and plant breeders to determine the likely return from managing pastures to promote greater pasture persistency and evaluate any trade-offs required.

\section{REFERENCES}

Bluett, S.J.; Thom, E.R.; Dow, B.W.; Burggraaf, V.T.; Hume, D.E.; Davies, E.; Tapper, B.A. 2004: Effects of natural reseeding and establishment method on contamination of a novel endophyte-infected perennial ryegrass dairy pasture with other ryegrass/ endophyte associations. New Zealand Journal of Agricultural Research 47: 333-344.

Bryant, J.R.; Ogle, G.; Marshall, P.R.; Glassey, C.B.; Lancaster, J.A.S.; García, S.C.; Holmes, C.W. 2010. Description and evaluation of the Farmax Dairy Pro decision support model. New Zealand Journal of Agricultural Research 53: 13-28.

Bryant J.R.; Lambert M.G.; Brazendale R.; Holmes C.W.; Fraser T.J. 2010b. Effects of integrated cropping and pasture renewal on the performance and profit of dairy farms. Proceedings of the $N Z$ Grasslands Association 72: 29-34.

Dalley D.E. 2010. Regrass your bottom line. Quoted in A. Lee. NZ Dairy Exporter 85(9): 26. 
Glassey C.B.; Roach C.G.;Strahan M.R.; McLean N. 2010. Dry matter yield, pasture quality and profit on two Waikato dairy farms. Proceedings of the NZ Grasslands Association 72: 91-96.

Gerrard P.J; Cooper B.M.; Eden T.M; Howlett S.A.; Lane P.M.S.; Panckhurst K.A.;Wilboroughy B.E.; Wilson D. J. 2009. Impact of ryegrass selection and paddock history on clover establishment in new dairy pasture. Proceedings of the New Zealand Grassland Association 71: 133-137.

Hainsworth, R.J.; Thomson, N.A.; McCallum, D.A.; Judd, T.G. 1991. Evaluation of dryland species and new ryegrass cultivars to increase pasture productivity in coastal Taranaki. Proceedings of the New Zealand Grassland Association 53: 55-58.

Kelly S.; Smith E. 2010. Pasture renewal in the Waikato and Bay of Plenty regions. Report prepared for DairyNZ. AgResearch, Hamilton, New Zealand. September 2010.
Kelly S.; Smith E.; Brazendale R. 2011. Farmer confidence, satisfaction and attitudes to pasture renewal: A survey of the Waikato and Bay of Plenty regions. Pasture Persistence. Grassland Research and Practice Series 15: 21-24.

McLean N. 2009. The impact of improving a dairy system by a pasture renewal programme. Report to Pasture Renewal Charitable Trust. Agriculture Business Associates. Hamilton, New Zealand.

Sanderson K.; Webster M. 2009. Economic analysvis of the value of pasture to the New Zealand economy. Report to the Pasture Renewal Charitable Trust. Business and Economic Research limited, BERL, Wellington, New Zealand. September 2009. 